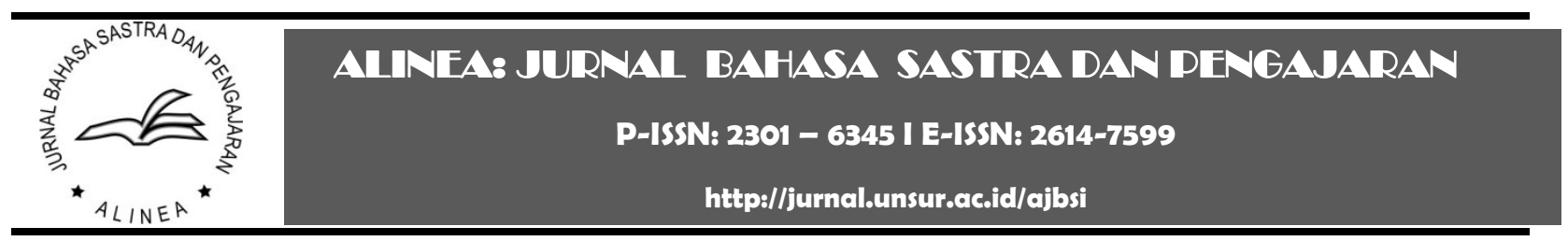

\title{
NILAI RELIGIUS DALAM NOVEL TITIP RINDU KE TANAH SUCI KARYA AGUK IRAWAN: KAJIAN SOSIOLOGI SASTRA
}

\author{
Vivian Nur Safitri \& Candra Rahma Wijaya Putra \\ Universitas Muhammadiyah Malang, Indonesia
}

Riwayat artikel:

Dikirim: 17 Juni 2020

Direvisi: 26 Desember 2020

Diterima: 27 Desember 2020

Diterbitkan: 27 April 2021

Katakunci:

religius, sabar, mulia, dan jujur

Keywords:

religious, patient, noble, and honest

Alamat surat

viviansafitri@gmail.com

\begin{abstract}
Abstrak:
Artikel ini mendeskripsikan nilai religius yang terepresentasikan dalam novel "Titip Rindu ke Tanah Suci”. Penelitian dilakukan menggunkan pendekatan kualitatif. Sumber data dalam penelitian yaitu novel. Fokus penelitian meliputi nilai-nilai religiusitas yang berhubungan manusia dengan Tuhan, manusia lain dan alam dan relevansi nilai religius dalam pembelajaran karya sastra di sekolah. Kedua aspek fokus tersebut diharapkan mampu melengkapi nilai-nilai religius yang saat ini banyak ditinggalkan oleh masyarakat maupun generasi muda. Penelitian diharapkan mampu mengingatkan seluruh masyarakat untuk selalu mewujudkan nilai-nilai religius dalam kehidupan sehari-hari. Nilai religius yang ditemukan dalam kajian ini meliputi rasa sabar menjadi manusia, memiliki akhlak yang mulia, dan menjadi manusia yang jujur.
\end{abstract}

\begin{abstract}
:
This article describes the religious values represented in the novel "Titip Rindu ke Tanah Suci". The research was conducted using a qualitative approach. The data source in this research was novel. The focus of research includes 1. Religious values related to human with God, other humans and nature, 2. Relevance of religious values in learning literary works in schools. These two aspects of focus are expected to be able to complete the religious values that are currently neglected by society and younger generation. This research is expected to remind society to always implement religious values in their daily life. The religious values found in this study include a sense of patience as a human being, having noble attitude, and being an honest human being.
\end{abstract}

\section{PENDAHULUAN}

Peradaban dan kehidupan bermasyarakat akan senantiasa berkembang secara dinamis. Banyak hal yang menyangkut sopan santun, budi bahasa maupun kebudayaan suatu bangsa menjadi tolak ukur dalam bermasyarakat.

Kehidupan yang membentuk suatu kelompok masyarakat dalam suatu daerah tidak terlepas dari banyaknya nilai dan aturan yang mendukungnya (Lubis 2017). Beberapa nilai di antaranya adalah nilai sosial, nilai moral, nilai politik, nilai budaya, dan nilai religius.

Penerapan kelima nilai bermasyarakat tersebut penting bagi setiap individu yang bertempat tinggal dalam suatu daerah. Akan tetapi, saat ini marak isu mengenai degradasi moral yang terkait dengan nilai religius memberikan dampak yang bersifat jangka panjang bagi masyakarat luas. Degradasi moral atau proses penurunan tingkat moral yang lebih tinggi ke lebih rendah dipandang seiring dengan penurunan kualitas hidup masyarakat dan bangsa. Salah satu wujud adanya degradasi moral saat ini terlihat adanya kemrosotan nilai-nilai religius pada masyarakat yakni maraknya fenomena hamil di luar nikah oleh anak-anak yang masih mengenyam pendidikan sekolah, terbukanya perizinan mengenai homo sek-sualitas atau LGBT di 
masyarakat, mening-katnya kecurangan politik oleh sebagian masyarakat yang beragama Islam dan beberapa kasus degradasi moral lainnya.

Salah satu contoh degradasi moral tersebut termasuk pada meningkatnya kenakalan remaja yang tidak menunjukkan tingginya tingkat kereligiusan seseorang (Palupi dkk, 2013). Apabila seseorang memiliki tingkat religiusitas yang tinggi, maka akan menunjukkan perilaku ke arah hidup yang religius, begitu sebaliknya jika tingkat religiusitas rendah, maka akan berperilaku ke arah hidup yang jauh dari religius pula (Palupi dalam Jalaluddin, 2013).

Degradasi moral berkaitan dengan perilaku menyimpang yang dipengaruhi oleh jiwa-jiwa yang bergejolak. Menurut Bintari (2014), perilaku menyimpang merupakan permasalahan psikologi yang ditunjukkan secara berulang-ulang dan diwujudkan dalam perilaku yang melanggar nilai-nilai atau norma-norma dalam masyarakat. Dengan terbentuknya pelanggaran tersebut menjadi cerminan bahwa rendahnya konsep diri dan nilai religiusitas dikalangan masyarakat masih perlu ditingkatkan.

Selain itu, kurangnya kepekaan masyarakat dan keterbatasan pengetahuan dalam menerapkan nilai-nilai tersebut juga menjadi akibat pada pudarnya akhlak setiap individu sehingga hal tersebut dipengaruhi pula oleh meluasnya globalisasi dan teknologi di suatu negara (Bakhri 2018). Perkembangan moral seseorang terjadi secara struktural pada pola pikir masyarakat dalam menjalankan kegiatannya. Disebutkan oleh Wulandari (2019) bahwa peran budaya menjadi salah satu dasar yang dapat mempengaruhi nilai, sikap dan perilaku seseorang. Dengan demikian, keterlibatan nilai-nilai religius dibalik maraknya degradasi moral saat ini adalah sangat penting sekaligus mampu menjadi kontrol diri menuju hal-hal yang lebih baik.

Penanaman dan penghayatan nilai-nilai religius tidak lagi menjadi tolak ukur seseorang untuk melakukan kegiatan yang bersifat sosial maupun pribadi. Akibatnya tidak banyak dari masyarakat yang sadar akan pentingnya nilai-nilai religius tersebut sehingga menyebabkan ketidakseimbangan antara kehidupan individu dengan lingkungan sekitarnya. Nilai merupakan peran penting dalam proses perubahan sosial, yang mana hal tersebut mampu menjadi pendorong untuk mengubah suatu tatanan masyarakat (Amin 2016).

Religiusitas merupakan nilai inti kualitas hidup manusia dengan dimensi yang berada di dalam lubuk hati sebagai riak getaran nurani pribadi dan menepas intimitas jiwa (Mangunwijaya dalam Gunawan, 2018). Kualitas religius masyarakat yang masih timpang dapat menyebabkan nilai masyarakat menjadi merosot. Hal tersebut banyak ditemukan dikalangan remaja yang mana pada zaman sekarang dengan mudah menyerap budaya barat dan bersifat bebas (Dya dalam Djarir, 2014).

Dengan demikian adanya kajian ini mampu mengangkat nilai religius untuk mengungkapkan berbagai persoalan kehidupan sosial yang dicitrakan oleh tokoh utama dalam sebuah novel. Selain itu, nilai religius dinilai mampu memiliki relevansi dalam pembelajaran karya sastra di tingkat sekolah guna untuk meningkatkan kualitas nilai moral yang banyak dilupakan oleh masyarakat.

Hubungan manusia yang berkaitan dengan nilai religius dapat disimpulkan menjadi tiga unsur antara lain hubungan manusia dengan Tuhan, hubungan manusia dengan manusia lain dan hubungan manusia dengan alam. Ketiga unsur tersebut mengartikan bahwa kehidupan religius manusia akan terikat satu sama lain dan nilai-nilai tersebut akan terus berkembang dalam lingkungan masyarakat. Seseorang yang melekat dengan nilai religius dalam dirinya cenderung memiliki hati nurani yang serius dan dekat dengan Tuhan dalam keadaan apapun.

Menurut Nuandri (dalam Andisti \& Ritandiyo, 2008) Religiusitas dan agama saling mendukung dan melengkapi karena keduanya merupakan konsekuensi logis dari 
kehidupan pribadi manusia dan kehidupan ditengah masyarakat. Keberadaan nilai religius meru-pakan salah satu representasi dari kehidupan seseorang dalam bentuk sikap, perilaku, komunikasi, maupun cara mendekatkan diri kepada Tuhan. Nilai religius mampu memberikan kesadaran batin bagi seseorang untuk berbuat kebaikan, pemahaman dan penghayatan terhadap nilai tersebut.

Terbentuknya nilai religius dalam masyarakat dapat ditemukan dalam repre-sentasi kehidupan fiksi manusia atau yang biasa disebut novel. Novel dapat disebut sebagai karya sastra yang mengungkapkan kehidupan luas manusia yang dapat berupa tantangan atau perjuangan tokoh fiksi maupun non fiksi. Karya sastra menawarkan pesan moral yang berhubungan dengan sifat luhur kemanusiaan, ilmu pengetahuan maupun semangat religius tokoh dalam cerita. Novel Titip Rindu Ke Tanah Suci karya Aguk Irawan merupakan novel dengan latar belakang religi yang menyajikan masalah kepercayaan agama dengan segala konflik sosial yang terjadi pada tokoh dalam cerita.

Kisah tokoh Emak yang mengabdikan dirinya untuk lebih mendekatkan diri kepada Tuhan ketika hari tuanya sudah tidak dapat ia tawar kembali. Novel tersebut menyajikan banyak nilai religius yang dicerminkan tokohtokoh dalam cerita termasuk tokoh utama yang bernama Emak yang bertekad menunaikan ibadah haji dengan segala kondisi dan ekonominya yang berada di kelas bawah.

Beberapa pembahasan mengenai nilai religius yang terdapat dalam novel juga dikaji sebagai bahan pembelajaran sastra yang sebelumnya ditulis oleh Aisah salah satu mahasiswi Pendidikan Bahasa Indonesia. Kajian tersebut mengungkap novel Kubah karya Ahmad Tohari yang menghubungkan pedalaman isi novel sebagai implementasi pembelajaran sastra di SMA (Aisah 2016). Selanjutnya, terdapat juga pembahasan nilai religius dalam novel Hafalan Shalat Delisa karya Tere Liye dan implikasinya terhadap pembelajaran apresiasi sastra di Sekolah
Menengah Atas yang ditulis oleh Gunawan. Penelitian tersebut mengungkap nilai-nilai religius yang terdapat dalam novel. Beberapa nilai religius termasuk berupa akidah, syariah dan akhlaq. Implementasinya pada pembelajaran dijadikan materi pembelajaran dan diterapkan dalam proses pembelajaran yang dituangkan dalam Rencana Pelaksanaan Pembelajaran di Sekolah Menengah Atas (Gunawan, 2020). Penelitian ketiga juga diperkenalkan oleh Nurmala dengan judul nilai-nilai religius pembentuk akhlak mulia dalam novel Assalamualaikum Beijing karya Asma Nadia (kajian struktural genetik). Kajian yang mengungkap nilai- nilai religius pembentukan akhlak mulia dalam novel dari segi struktur sosial masyarakatnya (Nurmala, 2017).

Perbedaan kajian yang akan dibahas pada penelitian ini yakni mengungkap nilai religius yang berhubungan dengan kehidupan sosial tokoh utama serta bagaimana relevansinya terhadap pembelajaran sastra di tingkat sekolah. Pembahasan mengenai nilai religius dikupas melalui unsur-unsur religiusitas yang berhubungan dengan kehidupan sosial masyarakat. Unsur-unsur religiusitas tersebut mencakup hubungan manusia dengan Tuhan, hubungan manusia dengan alam, serta hubungan manusia dengan manusia lainnya. Ketiga unsur religiusitas tersebut ditemukan dalam novel Titip Rindu ke Tanah Suci dan dikembangkan sehingg mampu membentuk nilai-nilai religius yang akan direlevansikan pada pembelajaran sastra di tingkat sekolah. Tiga unsur religiusitas ini disebutkan oleh Samidi (2016) merupakan unsur yang dijabarkan sesuai dengan adat dan budaya yang melingkupi. Hubungan manusia, Tuhan, dan alam secara umum sebagai satu kesatuan yang tidak dapat dipisahkan. Hal tersebut menjadi suatu keselarasan yang akan menjadi jalan untuk mendapatkan kebahagiaan dan kese-lamatan dunia dan akhirat.

Alasan pemilihan karya sastra tersebut antara lain merupakan kumpulan cerita yang terbit pada akhir tahun 2017. Karya sastra tersebut menggambarkan cerita religi yang inheren dengan kehidupan dan kondisi sosial 
masyarakat. Kisah inspiratif dari seorang tokoh Emak mampu memberikan motivasi serta mampu memandang bahwa karya sastra tidak hanya dinilai dari segi nilai sosialnya melainkan mampu dihubungkan dengan nilai religius yang bernuansa sosial kemasyarakatan. Nilai religius Islam digambarkan dalam masyarakat mampu mengatur seluruh sendi kehidupan manusia. Selain berisi hukum, aturan dan panduan kehidupan, syariat islam juga berisi kunci penyelesaian seluruh masalah manusia. Melalui nilai-nilai religius beberapa persoalan yang terkonflik dalam novel tersebut mampu diselesaikan melalui pandangan agama. Unsur religius dalam novel Titip Rindu Ke Tanah Suci karya Aguk Irawan sangat dominan, karena judul sudah mencakup dan mengandung makna nilai religius yang akan diuraikan dalam karya sastra tersebut.

Dalam karya sastra yang berlatar agama, pengarang akan menghadirkan unsur-unsur religius yang diharapkan mampu menambah ilmu agama, wawasan agama, dan akan menambah keimanan pembacanya pada Tuhan (Gunawan 2018). Novel Titip Rindu Ke Tanah Suci ini menggambarkan kehidupan seorang tokoh Emak yang berkeinginan untuk pergi ibadah haji. Segala tuntutan dan kewajiban mulai ia jalani seperti berjualan nasi di stasiun, belajar mengaji, mencari informasi tentang haji serta menabung sebagian rezeki untuk bekal pergi haji. Akan tetapi, perjalanannya tidak semulus yang dipikirkan oleh tokoh Emak, ia banyak mendapat gunjingan dan cercaan diberbagai pihak akan tetapi tekad dan semangatnya tidak luntur untuk tetap mewujudkan mimpinya.

Nilai-nilai religius yang berhubungan dengan kehidupan sosial tokoh Emak dapat ditemukan seiring dengan lika-liku perjalanan Emak ketika ingin menunaikan ibadah haji. Nilai-nilai religius terikat dengan tiga inti pokok yakni aqidah, syariah (ibadah dan muamalah), dan akhlak yang menjadi pedoman perilaku sesuai dengan aturan-aturan illahi untuk mencapai kesejahteraan serta kebahagian hidup di dunia dan akhirat (Sahlan dalam Gunawan, 2018). Tiga inti pokok religius tersebut dirumuskan dalam dua pembahasan penelitian ini antara lain, 1) Unsur-Unsur Religiusitas, 2) Relevansi Nilai Religius Karya Sastra Dalam Pembelajaran di Sekolah. Beberapa rumusan tersebut diajukan penulis mampu melatarbelakangi adanya relevansi antara nilai religius dan kehidupan sosial tokoh utama dalam novel Titip Rindu Ke Tanah Suci.

\section{METODE}

Penelitian ini menggunakan pendekatan sosiologi sastra yang berfokus pada teori religiusitas. Jenis penelitian ini bersifat deskriptif kualitatif dan memandang memandang nilai-nilai religius yang digambarkan dalam novel sebagai objek penelitiannya. Penelitian ini menggunakan metode kualitatif yang dengan demikian dibatasi oleh faktafakta sosial yang ditafsirkan oleh subjek yang bersangkutan (Ratna, 2013:47). Sumber data penelitian diambil dari novel yang berjudul Titip Rindu Ke Tanah Suci karya Aguk Irawan yang diterbitkan pada tahun 2017.

Data yang didapatkan berupa satuan cerita yang mengandung unsur-unsur religiusitas dan relevansi nilai religius karya sastra dalam pembelajaran di sekolah.

Pengumpulan data dalam penelitian ini dilakukan dengan teknik membaca, membuat instrumen penjaringan dan pengkodean data. Instrumen penjaringan data berguna untuk mengelompokkan data sesuai dengan aspekaspek yang akan ditulis dalam pembahasan penelitian ini.

Adapun langkah-langkah analisis data sebagai berikut: mendeskripsikan data setelah pengumpulan data dilakukan, menginterpretasikan data hasil telaah yang didapatkan dari membaca novel, menyimpulkan hasil analisis data sesuai penelitian.

\section{HASIL PENELITIAN}

Religius merupakan segala sistem menyangkut agama dan kepercayaan manusia kepada Tuhan. Menurut Mulyani (dalam 
Yusuf, 2019) religius berasal dari kata religi atau sama dengan agama. Penamaan kata religi tersusun dari " $r e$ " yang berarti "kembali" dan "ligere" yang berarti "terikat". Hal tersebut diartikan bahwa seorang manusia tidak memiliki kebebasan dalam hidup dan kemauannya sendiri melainkan harus menurut pada ketentuan hukum yang mengikat. Hukum yang dimaksud dalam artian pedoman dan ketentuan yang telah ditulis dan diterapkan oleh agama kepercayaan setiap manusia salah satunya agama islam. Agama sebagai sumber dari nilai-nilai religius merupakan sebagai petunjuk dan pedoman manusia untuk menyelesaikan segala persoalan dalam dunia seperti politik, ekonomi, sosial, dan budaya. Dari seluruh persoalan tersebut akan selalu menuju pada satu tujuan hidup dan perilaku yang menjunjung pada keridhoan Sang Pencipta Allah Subhanahu wa ta'ala yakni memecahkan masalah dunia dengan berpedoman pada nilai-nilai religius agama islam.

Oleh karena itu, wujud nilai-nilai religiusitas yang dicitrakan dalam novel Titip Rindu Ke Tanah Suci terbagi menjadi tiga unsur yang dirumuskan yakni hubungan manusia dengan Tuhan, hubungan manusia dengan Alam, dan hubungan manusia dengan manusia lainnya.

Dalam beberapa temuan penelitian diantaranya dengan novel yang berlatar agama juga memaparkan bahwa ketiga unsur religiusitas tersebut memperkuat adanya nilai religius yang ada dalam novel Titip Rindu ke Tanah Suci. Penelitian ini menawarkan pesan moral yang berpedoman pada nilai religius dan menjadi pedoman di setiap kehidupan manusia. Penelitian yang membahas nilai religius mampu dijadikan sebagai bahan pembelajaran sastra juga menjadi pedoman bahwa pembahasan nilai religiusitas menjadi latar belakang dari penelitian-penelitian lain. Hal tersebut memperkuat kajian ini untuk mengeksplorasi adanya hubungan atau relevansi antara nilai religiusitas dan pembelajaran sastra di sekolah. Beberapa nilai religius termasuk berupa akidah, syariah dan akhlaq (H. I. Gunawan, 2020) yang dalam penelitiannya menjadi pedoman sebagai apresiasi pembelajaran sastra di tingkat sekolah.

Beberapa kajian lainnya yang mengungkap tiga unsur nilai religiusitas mampu memperkuat penelitian-penelitian lainnya adalah penelitian yang ditulis oleh Sari (2018) yang menawarkan tiga unsur religiusitas yang membahas pada satu novel Assa-lamualaikum Beijing karya Asma Nadia. Pemaparan kajian tersebut menyimpulkan bahwa dengan berpedoman pada tiga unsur religiusitas, nilai-nilai dalam novel mampu diungkapkan dengan melihat pada indikator dan subindikator unsurunsur tersebut. Pembahasan nilai-nilai religius akan dipa-parkan dalam indikator unsur-unsur religiusitas sebagai berikut.

\section{Hubungan Manusia dengan Tuhan}

Hubungan antara Sang Pencipta dan yang diciptakan adalah suatu hubungan yang tidak dapat dipisahkan. Manusia memiliki keterikatan dengan Sang Pencipta sehingga mustahil untuk berpelepas diri. Hubungan antara Sang Pencipta dengan manusia telah dimiliki sejak zaman dahulu terciptanya manusia pertama kali di bumi. Mereka mendudukan Allah sebagai Tuhan bagi umat muslim dan meyakini-Nya sebagai pemilik alam semesta. Salah satu hal penting untuk membina hubungan dengan Sang Pencipta adalah manusia harus mengenal betul Allah dengan segala syariatnya. Keimanan dan ketakwaan yang dimiliki seorang muslim akan tercermin dalam melaksanakan ibadah dan kewajiban-kewajiban yang lainnya yang memiliki akhlak mulia dengan manusia lainnya. Ada beberapa bentuk hubungan manusia dengan Tuhan salah satunya dalam hal beribadah yang ditemukan dalam novel Titip Rindu Ke Tanah Suci. Beribadah kepada Tuhan merupakan sikap naluriah yang timbul dari dalam diri manusia untuk selalu menerima dan menjalankan segala perintah serta ketentuan yang diberikan Allah. Hal tersebut terdapat dalam kutipan novel Titip Rindu ke Tanah Suci.

"Berbeda dengan emaknya. Didapatinya sang emak mengerjakan shalat Shubuh terlebih dahulu sebelum 
30 Alinea: Jurnal Bahasa, Sastra, dan Pengajaran

Volume 10, (1) April 2021, hal. 25-36

berangkat ke stasiun. Di stasiun, emaknya - juga dirinya - pun menyempatkan diri shalat Zhuhur."

Dalam kutipan di atas menggambarkan tokoh Emak yang begitu patuh dan tekun dalam beribadah kepada Allah. Adanya sikap tersebut terbentuk dari rasa cinta kepada Sang Pencipta yang telah memberikannya nikmat kehidupan. Dalam hal ini dapat diketahui bahwa faktor seorang muslim mampu memiliki hubungan dekat dengan Sang Pencipta karena dalam hidupnya senantiasa mengikuti segala perintah dan ketentuan-Nya. Oleh karena itu, setiap manusia yang memiliki rasa cinta terhadap Tuhannya akan selalu menjadikan ibadah dan doa sebagian bagian dari kewajibannya. Bekerja hanya mampu memenuhi kebutuhan sebagian jasmaninya tetapi ibadah dan doa tidak hanya memenuhi kebutuhan jasmani melainkan rohani.

Sebagai seorang yang percaya akan keberadaan Tuhan sebagai Sang Pencipta alam semesta, seorang muslim harus selalu memiliki rasa rindu kepada Tuhan. Hal tersebut untuk meyakinkan diri bahwa setiap manusia tidak hanya membutuhkan manusia lain untuk selalu membantunya melainkan membutuhkan kuasa yang lebih dari manusia untuk menyelesaikan segala persoalan hidupnya. Rasa rindu yang yang dimiliki manusia kepada Tuhannya akan selalu memberikan kekuatan terhadap diri seseorang bahwa ia tidak sendirian melainkan selalu menjadi objek pengawasan Tuhan. Dalam hubungan manusia dengan Tuhan ditandai dengan adanya rasa rindu kepada Sang Pencipta. Hal tersebut terdapat dalam kutipan novel berikut.

"Mak selama ini hanya bisa bacaan shalat. Itu pun hafalan saja. Ndak tahu bener-ndaknya. Intan, Mak pengin mengaji supaya bisa baca al-Quran. Mak pengin naik haji, Intan!"

"Saya punya cita-cita. Cita-cita yang entah kapan bisa terwujud. Saya ingin menjalankan rukun islam yang kelima."
Bentuk nyata pertemuan seseorang dengan Sang Pencipta yang direfleksikan dalam agama islam adalah ketika ia berkunjung dan beribadah ke Mekkah atau ibadah haji. Berhaji merupakan salah satu inti tradisi umat islam yang dilakukan oleh manusia untuk mempererat rasa rindunya kepada Tuhan. Rasa rindu dalam diri seorang manusia akan tercipta seiring dengan rasa percaya dan rasa cinta manusia kepada Sang Pencipta. Ketika hubungan tersebut dihadapkan kepada Tuhan maka seseorang akan menunjukkan usaha untuk bertemu dengan Sang Pencipta yang direfleksikan melalui sikap beribadah dan doa-doa mustajab dalam waktu tertentu. Ibadah naik haji sudah menjadi cita-cita yang selalu dimiliki oleh setiap umat muslim agar senantiasa terciptanya rasa lebih dekat dengan Tuhan. Menjadi lebih dekat dan menjalankan seluruh perintahnya salah satunya beribadah Haji yang akan dilakukan oleh tokoh Emak.

Semangat dan usaha tokoh Emak berharap akan membuahkan hasil untuk segera menunaikan ibadah haji. Keinginan tokoh Emak untuk menunaikan ibadah haji sematamata dilandasi oleh rasa rindunya akan kehadiran Tuhan dalam hidupnya. Kesadaran hati dan tingkah laku untuk mengaji yang dilakukan oleh Emak menjadikan dirinya percaya bahwa memiliki rasa rindu terhadap Tuhan harus diimbangi dengan rasa patuhnya terhadap perintah yang diberikan oleh-Nya. Salah satunya perintah mengaji dan hafalan surah-surah dalam Al-Quran. Nilai religius yakni senantiasa memiliki rasa rindu terhadap Tuhan juga berhubungan dengan nilai religius yang pertama yakni patuh dan tekun dalam beribadah. Dengan demikian, rasa rindu kepada Sang Pencipta tidak lain adalah refleksi dari tindakan mencintai Tuhan dengan menerapkan dan menjalankan perintah ibadah dalam kehidupan seseorang. Kutipan di atas menjadi dasar bahwa adanya keterkaitan antara sikap religius yang mampu meningkatkan rasa percaya dalam diri seseorang. Tidak hanya kepada Tuhan melainkan seluruh kehidupan yang diatur oleh-Nya. Disebutkan oleh Fitriani bahwa 
peran religiusitas juga menerapkan kesejahteraan psikologis yang menuju pada kemantangan individu. Kesejahteraan psikologis tersebut menerangkan bahwa seseorang yang memiliki sikap positif terhadap diri sendiri maka tidak akan cepat berputus asa dan percaya sepenuhnya dengan kuasa Tuhan (Fitriani, 2016).

Selain nikmat ibadah akan mengantarkan manusia pada kesejahteraan psikologis, hubungan manusia dengan Tuhan juga dapat diwujudkan dengan mengakui kekuasan dan kebesaran Tuhan dalam hidupnya. Menjadi manusia yang taat dan bersyukur atas nikmat yang Allah berikan merupakan salah satu hubungan manusia dengan Tuhan yang diwujudkan sebagai ibadah. Ibadah kepada Tuhan tidak hanya dalam hal menomorsatukan diri beribadah dan memiliki waktu berdua dengan Tuhan melainkan mengingatkan diri untuk memiliki rasa syukur atas nikmat yang diberikan juga merupakan wujud ibadah. Perwujudan rasa syukur tersebut terdapat dalam kutipan novel Titip Rindu ke Tanah Suci.

"Ndak ada salahnya bermimpi. Setiap orang ingin bisa menjalankan ibadah suci. Gusti Allah memberi rezeki dari mana pun datangnya. Kadang terduga, kadang tidak terduga."

Dalam kutipan di atas menggambarkan percakapan antara tokoh Emak dan tokoh Intan sekaligus anak perempuan Emak Siti dalam novel. Tokoh Emak yang begitu gigih untuk meraih impiannya dan yakin kepada Allah bahwa Allah akan mengabulkan segala doa-doa hambanya. Bersyukur dan percaya bahwa Allah akan memberi rezeki kepada hambanya adalah salah satu bentuk hubungan manusia dengan Tuhannya. Tidak hanya bersyukur tentang kehidupan dan segala rezeki yang diberikan melainkan diwujudkan melalui tindakan-tindakan lainnya salah satunya berusaha untuk mewujudkan keinginan beribadah haji. Keinginan tokoh utama untuk beribadah Haji dan yakin bahwa rezeki manusia akan datang tanpa disangka-sangka membuktikan adanya keimanan dalam hati seorang manusia. Kepercayaan tersebut didukung dengan ilmu, seperti yang disebutkan oleh Amin bahwa ada dua jenis ilmu yaitu ilmu yang sudah cukup dengan mengetahui tanpa harus mengamalkannya dan ilmu yang tidak cukup hanya dengan diketahui saja, tapi juga harus diamalkan, seperti ilmu tentang ibadah kepada Tuhan (Amin, 2015). Kutipan percakapan oleh tokoh Emak mendukung adanya ilmu yang harus diketahui dan diamalkan yakni ilmu beribadah kepada Tuhan.

Setiap manusia yang hidup dalam suatu negara akan memiliki panduan dan aturan untuk menjadi masyarakat yang baik. Begitu pula dengan manusia yang memiliki kepercayaan adanya hubungan dengan Tuhan. Perintah dan larangan Allah senantiasa dijabarkan dan ditafsirkan dalam Al-Quran dan As-Sunnah. Segala sesuatu yang menyangkut kehidupan manusia di bumi untuk menjadi umat muslim yang dekat dengan Allah akan selalu menaati dan mematuhi perintah dari-Nya. Adanya hubungan manusia dengan Tuhan yang terpenting ditandai dengan niat dan serius dalam belajar agama. Langkah seseorang dalam mengambil tindakan akan dinilai seberapa banyak partisipasi seseorang tersebut dalam melakukan sesuatu. Begitu pula dengan seorang muslim yang meyakini dirinya bahwa ada kekuasaan yang besar selain dari manusia itu sendiri dan wajib untuk dikerjakan. Salah satunya adalah dengan belajar mengaji dan menuntut diri untuk selalu berusaha keras dalam konsisten dalam belajar. Beribadah kepada Tuhan adalah prioritas setiap manusia yang sewajarnya memiliki hubungan pribadi dan tidak bergantung dengan orang lain. Oleh karena itu, sikap yang telah dicitrakan oleh tokoh Emak dalam menjalin hubungan dengan Tuhan adalah mampu dikategorikan sebagai nilai religius dalam hal beribadah kepada Sang Pencipta.

\section{Hubungan Manusia dengan Alam}

Nilai religiusitas yang dapat dilakukan manusia salah satunya mencakup hubungannya dengan alam. Semakin baik hubungan seseorang dengan mengakui 
keberadaan alam atas ciptaan Sang Pencipta semakin tinggi pula rasa cintanya kepada Tuhan. Hubungan manusia dengan alam dapat dilakukan dengan sikap syukur atas terciptanya alam semesta. Dalam novel Titip Rindu Ke Tanah Suci juga merepresentasi nilai religiusitas manusia yang memiliki hubungan dengan alam. Salah satunya yang dicitrakan oleh tokoh dalam novel tersebut. Berikut kutipannya.

"Debu-debu Sahara berterbangan. Terik sang surya mulai membakar jalanjalan mulus beraspal. Daun-daun kurma menari-nari diembus angina. Lautan manusia bergerak dalam cinta dan kerinduan, mengelilingi Ka'bah, menyorongkan pujian. Dan di antara lautan manusia itu, sesosok tubuh tua nan ringkih sujud di atas lantai. Cahaya keluar berpijar-pijar dari tubuhnya. Lantai basah dengan air matanya. Air mata kerinduan dan cinta kepada Tuhan-Nya. Mak Siti, orang tua itu, terus saja sujud dan bersujud. Sujud terakhir. Sujud untuk selama-lamanya”

Dalam kutipan di atas menggambarkan bahwa manusia akan selalu berhubungan dengan alam di manapun mereka berada. Tokoh Emak berada diantara ribuan jamaah lainnya yang pergi menunaikan haji. Dengan perasaan bangga ia mengagumi seluruh titik tempat beribadah yakni Ka'bah. Tokoh Emak sebagai seorang muslim mengakui segala keberadaan dan keberadaan Tuhan bahwa doadoa yang telah diucapkan akan terkabul suatu saat nanti. Cita-cita Emak untuk bisa menunaikan haji terwujud dengan lika-liku yang melingkupinya. Melihat tokoh Emak mengagumi segala ruas bangunan Ka'bah menjadi bukti bahwa manusia akan menempatkan kekuasaan Tuhan seiring dengan rasa cintanya kepada Sang Pencipta.

\section{Hubungan Manusia dengan Manusia}

Hubungan antara manusia dengan manusia lain merupakan hubungan yang kompleks. Hidup bersosial membuat manusia saling bergantung dengan manusia lainnya sehingga timbul adanya interaksi dan komunikasi dalam suatu lingkungan. Masyarakat merupakan kumpulan dari orang-orang yang memiliki kehidupan dalam suatu daerah dan terikat akan kebudayaan daerah tersebut. Oleh karena itu, hubungan yang terjalin antara manusia dengan manusia lainnya akan tercipta jika ada kehidupan bersama secara terusmenerus. Interaksi antar masyarakat juga dipengaruhi oleh tingkat religiusitas seseorang. Sama ketika seseorang memiliki tingkat religiusitas yang baik maka perilaku yang ditampakkan oleh seseorang tersebut juga baik dan akan mendapatkan penilaian dari lingkungan sekitar. Menurut Reza (2013) penilaian dari lingkungan sekitar memiliki dua nilai, yaitu nilai baik dan nilai buruk. Penilaian dari masyarakat mengenai perilaku yang ditampakkan disebut dengan moral. Dengan demikian, moral juga dipengaruhi oleh hal-hal yang menyinggung nilai-nilai religiusitas yang ada pada diri seseorang.

Dalam novel Titip Rindu ke Tanah Suci terdapat hubungan manusia dengan manusia lainnya yang mana hal tersebut terjadi interaksi antar tokoh dalam novel. Salah satu sikap yang tercermin adalah sikap saling menghormati dan jujur. Interaksi antara manusia dengan manusia lainnya akan terjadi dengan baik ketika di dalamnya dipengaruhi oleh etika dan norma yang seimbang. Salah satunya adanya sikap saling menghormati kepada sesama manusia. Terciptanya komunikasi dan interaksi yang baik sesama manusia akan menimbulkan kebahagiaan dan kepuasan hati pada kedua belah pihak. Interaksisosial yang dilakukan mansyarakat akan sukses jika manusia itu mampu melakukan human relations dengan baik. Berikut salah satu kutipan yang menyatakan sikap saling menghormati dan jujur sesama manusia.

Mak Siti yang memang tak terbiasa berbohong dan selalu jujur, menjawab, "Iya mau minta izin sama Bu Haji, ikut ngaji.."

Salah satu wujud sikap saling menghormati telah dilakukan oleh tokoh Emak dalam novel Titip Rindu ke Tanah Suci. Hal 
tersebut mencerminkan bahwa sebagai umat beragama diharuskannya memiliki sifat saling menghormati antar sesama. Menjauhi segala sifat dan tindakan yang dibenci oleh Sang Pencipta. Manusia terikat dengan kehidupan sosial itu artinya dalam berorganisasipun manusia tidak dapat hidup sendiri. Hal tersebut juga diajarkan dalam hidup bergama. Ibadah tidak hanya dilakukan perseorangan melainkan dilakukan bersama dengan manusia lainnya. Dalah satu sikap yang tercermin untuk berhubungan baik dengan manusia lain adalah adanya sikap dalam menjalin tali silahturrahim. Sikap ini tercermin sebagai sebuah ibadah kepada Sang Pencipta dengan perantara melalui manusia itu sendiri. Adanya interaksi dan hubungan baik sesama manusia artinya kehidupan ibadah dan hubungan manusia itu sendiri dengan Tuhan juga terjalin dengan baik. Berikut kutipan dalam novelnya.

"Tentu yang hendak emak temui itu Bu Haji, Nduk. Bukan Pak Haji. Emak ingin belajar ngaji pada Bu Haji.”

Tokoh Emak dalam novel tersebut mencerminkan pribadi yang baik dalam menjalin silaturrahmi dengan manusia lainnya. Hal tersebut diiwujudkan dengan sikap Emak Siti yang ingin serius belajar mengaji kepada $\mathrm{Bu}$ Haji. Sikap tersebut sekaligus mencerminkan tindakan kepercayaan seorang muslim kepada muslim lainnya. Wujud dari sikap tersebut adalah adanya saling komunikasi dengan muslim lainnya untuk selalu menjalin tali silahturrahmi. Dalam kutipan di atas menunjukkan bahwa tingkat religiusitas seseorang juga memengaruhi hubungan manusia dengan manusia lainnya. Hal tersebut termasuk dalam keterlibatan hubungan positif dengan orang lain yang mana tokoh utama memiliki kemampuan dalam mengadakan hubungan interpersonal yang hangat dan saling mempercayai dengan orang lain (Fitriani 2016). Keterlibatan hubungan dengan orang lain digambarkan oleh tokoh Emak yaitu dengan hubungan komunikasi secara lisan ketika ingin menunaikan keinginannya untuk belajar mengaji.

\section{Nilai Religiusitas Karya Sastra Dalam Pembelajaran di Sekolah}

Dari pembahasan di atas dapat dilihat adanya relasi antara hubungan manusia dengan Tuhan, manusia dengan manusia, dan manusia dengan lingkungan. Seperti pada diagram berikut.

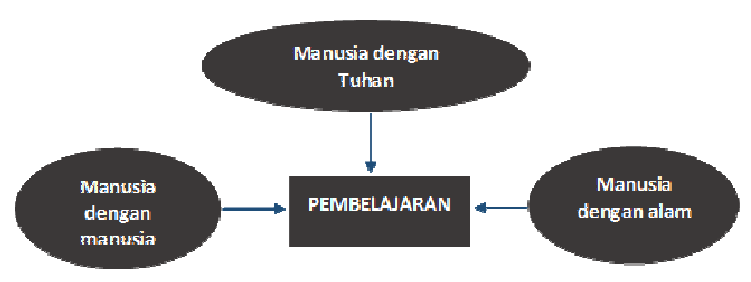

Pendidikan merupakan proses yang tidak bisa lepas dari materi akademik maupun non akademik. Agama islam menempatkan pendidikan sebagai bagian dari pembentukan generasi muda yang selalu menjunjung nilainilai religius yang berpedoman pada ajaran Sang Pencipta Allah SWT. Ketiga unsur nilai religiusitas ini menyatu menjadi satu kesatuan yang dinamakan sistem norma Ilahi. Hal tersebut memiliki tumpuan bahwa religiusitas yang ada pada diri seseorang tidak hanya diterapkan sebagaimana hubungannya dengan Tuhan melainkan dengan manusia dan juga alam sekitar. Dari bagan di atas dapat dilihat bahwa unsur-unsur religiusitas yang tumbuh dalam kehidupan manusia dapat direlevansikan dalam pembelajaran guna menunjang kompetensi untuk mengetahui nilai-nilai moral pada suatu karya sastra. Pembelajaran merupakan proses yang melibatkan antara pendidik dan peserta didik dalam upaya mencapai tujuan tertentu. Keterlibatan nilainilai religius dalam pembelajaran karya sastra akan menjadi tolak ukur dalam membentuk identitas peserta didik.

Penerapan pembelajaran sastra di sekolah memiliki tiga aspek tujuan yakni kognitif, afektif, dan psikomotorik. Ketiganya memiliki hubungan dengan pengembangan akademik maupun non akademik peserta didik. Dengan adanya penanaman nilai religius dalam pembelajaran sastra selain bisa sebagai tolak ukur pendidikan karakter peserta didik, guru juga bisa menggunakan novel sebagai bahan ajar dalam pembelajaran. Pengajaran sastra dapat membantu pendidikan 
secara utuh apabila cakupannya meliputi empat manfaat, yaitu membantu keterampilan berbahasa, meningkatkan pengetahuan budaya, mengem-bangkan cipta dan rasa, dan menunjang pembentukan watak (Rahmanto dalam Gunawan, 2020). Dalam pembelajaran juga perlu adanya penanaman karakter religius agar generasi muda bisa menunjukan eksistensi bangsanya. Adanya penanaman karakter tersebut di sekolah karena Sekolah dan peserta didik adalah unsur utama dalam pendidikan formal. Sekolah merupakan organisasi layanan yang melakukan kegiatan belajar dan mengajar antara pendidik dan peserta didik (Bakhri, 2018).

Nilai-nilai religius yang dapat direfleksikan dari novel Titip Rindu Ke Tanah Suci karya Aguk Irawan antara lain tekun dalam beribadah, pandai bersyukur, jujur dalam segala hal, dan memiliki sikap sabar dan tawakal. Penanaman nilai religius dalam pembelajaran tidak hanya mengiringi pendidikan akademik peserta didik namun juga mampu mengembangkan karakter peserta didik. Pengembangan karakter peserta didik dapat dilakukan dalam proses pembelajaran yang menanamkan sejumlah norma ke dalam jiwa anak didik. Selain itu, penanaman nilainilai religius dapat diwujudkan dalam pembelajaran yang meliputi komponen pengetahuan dan tindakan untuk melaksanakan nilai-nilai moral baik terhadap Tuhan Yang Maha Esa, diri sendiri, sesama, maupun lingkungan. Beberapa penanaman nilai religius yang berhubungan dengan pembelajaran karya sastra di sekolah diantaranya: (1) Rasa syukur, sikap religius yang diwujudkan pada nilai karakter dalam hubungannya dengan Tuhan. Dalam hal ini menyatakan bahwa segala pikiran, perbuatan, dan tindakan seseorang diupayakan harus memenuhi nilainilai Ketuhanan salah satunya adalah memiliki rasa syukur. (2) Memiliki sikap jujur, perilaku yang termasuk dalam nilai yang berhubungan dengan Tuhan serta manusia. Perwujudan sikap jujur seseorang akan berkaitan dengan bagaimana sikap jujurnya terhadap Tuhan yang direfleksikan melalui tindakan beribadah dan meneladani sifat-sifat baik lainnya sehingga mendorong diri untuk percaya bahwa Tuhan akan selalu mengawasi disetiap tindakan dan perbuatan kita. (3) Selalu sabar dan tawakal, sikap berikut dihadapkan pertama kali yang berhubungan dengan Tuhan. Sikap sabar dan tawakal akan terwujud bagi seseorang yang memiliki religiusitas dalam dirinya. Sikap ini dapat direlevansikan dalam pembelajaran untuk mendorong peserta didik memiliki rasa sabar dalam menyelesaikan persoalan dalam lingkup belajar di sekolah.

Adanya keterkaitan hubungan manusia dengan Tuhan, manusia dengan manusia lain, dan manusia dengan alam mengajarkan bahwa sikap seseorang ketika sebelum mendapatkan pembelajaran akan tersalurkan dari ketiga unsur nilai religiusitas tersebut. Keterkaitan nilai religius tersebut dimanfaatkan untuk membentuk karakter peserta didik melalui media pembelajaran karya sastra yang ada di sekolah. Selain penerapan nilai-nilai religius karya sastra dapat dijadikan sebagai materi pembelajaran yang diharapkan mampu mengandung nilai-nilai positif untuk mengembangkan serta menambah wawasan peserta didik. Selain itu, dengan adanya keterikatan nilai religius dalam pembelajaran sastra diharapkan peserta didik mampu mengimplementasikan nilai-nilai religius tersebut dalam kehidupan sehari-hari. Pengajaran sastra saat ini membutuhkan pendidik yang terampil dalam bidang untuk menyampaikan pesan atau nilai-nilai yang terkandung dalam sastra itu sehingga peserta didik mampu menerima pesan tersebut dengan baik.

\section{SIMPULAN}

Berdasarkan penelitian di atas terdapat keterkaitan antara pembelajaran dengan nilainilai religius yang dapat menjadi pedoman untuk meningkatkan karakter peserta didik di sekolah. Analisis nilai-nilai religius tidak hanya sebagai pengupasan masalah social yang ada dalam diri tokoh dalam novel Titip Rindu ke Tanah Suci melainkan dapat diimplementasi-kan sebagai pedoman untuk membentuk karakter peserta didik yang religius dan mampu menjadikan karya sastra 
sebagai sarana pembelajaran. Kegiatan belajar mengajar yang mana akan merujuk pada satu tujuan tertentu dengan mengiringi perkembangan karakter peserta didiknya. Tingkat karakter tersebut dapat didorong dengan menanamkan nilai-nilai religi yang terdapat dalam karya sastra Titip Rindu Ke Tanah Suci sebagai salah satu novel berlatar religi yang akan menjadi sarana pembelajaran. Tidak hanya itu penanaman karakter dapat dilakukan dengan mengadaptasi, menyelaraskan, membiasakan, dan menginteg-rasikan kepada peserta didik untuk selalu mewujudkan hubungan dengan Tuhan, hubungan dengan manusia lain, dan hubungan dengan Alam. Oleh karena itu, tiga unsur nilai religiusitas yang menjadi pedoman manusia dalam hidup bersosial tidak hanya dapat dilakukan dalam kehidupan masyarakat saja melainkan dapat diterapkan dalam proses pembelajaran guna lebih mengintensifkan lagi nilai-nilai religius yang saat ini telah diterapkan di masyarakat.

\section{DAFTAR PUSTAKA}

Aisah. 2016. "Nilai Religius pada Novel Kubah Karya Ahmad Tohari: Tinjauan Sosiologi Sastra dan Implementasinya Sebagai Bahan Pembelajaran Sastra di SMAN 2 Sukoharjo." Naskah Publikasi : Program Studi Pendidikan Bahasa Indonesia, Universitas Muhammadiyah Surakarta.

Amin, Muhammad. 2016. "Sosialisasi Nilai-Nilai Agama di Kalangan Mahasiswa Program Studi Sosiologi Agama UIN Sunan Kalijaga." Jurnal Sosiologi Agama: Jurnal Ilmiah Sosiologi Agama dan Perubahan Sosial Volume 10(Nomor 2).

Amin, Surahman dan Siregar. 2015. "Ilmu Dan Orang Berilmu dalam Al-Quran: Makna Etimologis, Klasifikasinya, dan Tafsirnya." Jurnal Emprisma Volume 24(Nomor 1).

Bakhri, Syamsul dan Alan Sigit Fibrianto. 2018. "Hubungan Kegiatan Ekstrakurikuler Pramuka dengan Tingkat Religiusitas Siswa SMA Negeri 1 Tangen (Perspektif Teori Sistem Sosial Talcott Parsons)." Jurnal Sosiologi Agama: Jurnal Ilmiah Sosiologi Agama dan Perubahan Sosial Volume 12(Nomor 1).

Bintari, Dantes, dan Sulastri. 2014. "Korelasi Konsep Diri dan Sikap Religiusitas Terhadap Kecenderungan Perilaku Menyimpang di Kalangan Siswa pada Kelas XI SMA Negeri 4 Singaraja Tahun Ajaran 2013/2014.” E-Journal Undiksa Jurusan Bimbingan Konseling Volume 2(Nomor 1).

Dya Pradisukmawati, dan Eko Darminto. 2014. "Hubungan Antara Tingkat Religiusitas dengan Tingkat Aktivitas Seksual pada Remaja Akhir.” Psympathic, Jurnal Ilmiah Psikologi Volume 1(Nomor 2).

Fitriani, Annisa. 2016. "Peran Religiusitas dalam Meningkatkan Psychological Well Being." AlAdyan: Jurnal Studi Lintas Agama Volume XI(Nomor 1).

Gunawan, Andry. 2018. "Nilai-Nilai Religius dalam Novel Ayat-Ayat Cinta 2 Karya Habiburrahman El Shirazy dan Rancangan Pembelajaran Sastra di SMA/MA." Skripsi S1 : Program Studi Pendidikan Bahasa dan Sastra Indonesia, Universitas Lampung.

Gunawan, Heri Indra. 2016. "Nilai Religius dalam Novel Hafalan Shalat Delisa Karya Tere Liye Dan Implikasinya Terhadap Pembelajaran Apresiasi Sastra di Sekolah Menengah Atas (Kajian Struktural Genetik Dan Analisis Isi)." Eduka : Jurnal Pendidikan, Hukum, Dan Bisnis Volume 2,.

Irawan, Aguk. 2017. Titip Rindu Ke Tanah Suci. Jakarta: Rupublika.

Lubis, M. Abduh. 2017. "Budaya dan Solidaritas Sosial dalam Kerukunan Umat Beragama di

Tanah Karo.” Sosiologi Agama: Jurnal Ilmiah Sosiologi Agama dan Perubahan Sosial Vol. 11(Nomor 2).

Mulyani, Sri. 2019. "Peran Pembina Asrama dalam Menanamkan Nilai-Nilai Religius Melalui 
Kegiatan Keagamaan pada Santri Putri Pondok Pesantren Nurul Islam Tengaran Tahun 2019." Institut Agama Islam Negeri Salatiga.

Nuandri, dan Widayat. 3014. "Hubungan Antara Sikap Terhadap Religiusitas dengan Sikap Terhadap Kecenderungan Perilaku Seks Pranikah pada Remaja Akhir Yang Sedang Berpacaran Di Universitas Airlangga Surabaya." Jurnal Psikologi Kepribadian dan Sosial Volume 3(Nomor 2).

Nurmala, Lala. 2017. "Nilai-Nilai Religius Pembentuk Akhlak Mulia dalam Novel Assalamualaikum Beijing Karya Asma Nadia (Kajian Struktural Genetik).” UHAMKA Graduate School Thesis Abstract Collection Volume 2.

Palupi, Purwanto, dan Noviyani. 2013. "Pengaruh Religiusitas Terhadap Kenakalan Remaja." Educational Psychology Journal Volume 2(Nomor 1).

Ratna, N. K. 2004. Teori, Metode, dan Teknik Penelitian Sastra. Cetakan 1. Yogyakarta: Pustaka Pelajar.

Reza, Iredho Fani. 2013. "Hubungan Antara Religiusitas dengan Moralitas pada Remaja di Madrasah Aliyah (MA)." Jurnal Humanitas Volume X(Nomor 2).

Samidi. 2016. "Tuhan, Manusia, dan Alam: Analisis Kitab Primbon Atassadhur Adammakna." Shahih Journal of Islamicate Multidisciplinary Volume 1(Nomor 1):24.

Sari, Nazella Putri, Ali Mustofa, dan Munaris. 2018. "Nilai Religius dalam Novel Assalamulaikum Beijing Karya Asma Nadia dan Implikasinya." Jurnal Kata (Bahasa,Sastra, dan Pembelajarannya).

Wulandari, Luluk. 2019. "Pengaruh Religiusitas Terhadap Perkembangan Moral Siswa Menengah Atas." in Magister Psikologi. Malang: Prosiding Seminar Nasional \& Call Paper. 